Article

\title{
Perceived Organizational Performance in Recruiting and Retaining Employees with Respect to Different Generational Groups of Employees and Sustainable Human Resource Management
}

\author{
Zdenka Gyurák Babel'ová *(D), Augustín Stareček ${ }^{(D)}$, Kristína Koltnerová ${ }^{(D)}$ and \\ Dagmar Cagáňová $\mathbb{D}$
}

Institute of Industrial Engineering and Management, Faculty of Materials Science and Technology in Trnava, Slovak University of Technology in Bratislava, Jána Bottu č. 2781/25, 91724 Trnava, Slovakia; augustin.starecek@stuba.sk (A.S.); kristina.koltnerova@stuba.sk (K.K.); dagmar.caganova@stuba.sk (D.C.)

* Correspondence: zdenka.babelova@stuba.sk

Received: 29 October 2019; Accepted: 10 January 2020; Published: 12 January 2020

check for updates

\begin{abstract}
Organizational performance is considered as the essence of an industrial enterprises' existence. However, in terms of performance, it is important not only to achieve results, but also maintain and develop the potential of an enterprise. When assessing performance, industrial management often omits the organizational success in managing human resources and developing human resources potential. The main aim of this paper is to present the research results focused on perceived organizational performance in recruiting and retaining employees with respect to different generations of employees in industrial enterprises. For the purposes of the analysis, the authors of the paper have designed a valid and reliable collection tool (research questionnaire). The research sample consisted of $\mathrm{N}=1471$ respondents, employees of industrial enterprises in the Slovak Republic. The research result shows that different generations of employees perceive differently selected issues of organizational performance. Testing the first research hypothesis has proved that there is a significant difference between employees from different generational groups in the perception of relationships among employees. The testing of the second research hypothesis confirmed that there is a statistically significant relationship between selected issues of perceived organizational performance.
\end{abstract}

Keywords: generational groups; performance; relationship; retention; sustainable human resource management

\section{Introduction}

A meaningful utilization of the enterprises' human resources is a precondition for taking advantage of the human resources potential. In order to enable the employees in an organization to perform at the required performance level, it is indispensable for them not only to have created the necessary conditions [1-3] but also to have the required competencies [4-6]. However, it is also important that they are sufficiently motivated [7,8] or engaged [9] to perform. These factors affecting work performance can be influenced by targeted activities and practices of human resource management. The basic precondition is that the organization dispose the human resources with necessary potential [10]. In this respect, the recruiting and retaining the staff plays an important role in ensuring the conditions for employees' performance.

The aim of the paper is to present the research focused on examination of perceived organizational performance and human resource management procedures, aimed at recruiting and retaining the employees with respect to different employees' generations in industrial enterprises. In order to 
achieve the research goal, it was necessary to analyze the perception of co-workers relations among various generational groups and perception of organizational performance issues connected with staffing and retaining the employees.

\section{Theoretical Background and Hypotheses}

The performance of an enterprise is steadily and significantly determined by the performance of processes and the performance of human resources, employees. It is important for enterprises to optimize and improve their processes constantly, otherwise they are at risk of downfall and extinction. Improving the quality of products, processes and the harmonious flow of business activities can be achieved through the right selection and systematic use of new quality improvement concepts, approaches and methods [11].

The importance of the quality of internal processes for business performance is emphasized by several authors [12-15]. In order to maintain sustainable business performance, it is important to focus not only on quality management systems, business performance measurements and evaluation concepts, but also to apply a competencies-based approach [16]. Some studies confirmed that human resource practices have a significant impact on organizations performance [17-19]. Nevertheless, human resources are usually insufficiently utilized because employees often carry out their work performance below the maximum potential. Human resource management organization practices aimed at inducing voluntary efforts from employees likely to yield returns that exceed the costs involved. Human resource management practices can influence such voluntary efforts [20].

Human resource management practices have been proven to increase organizational efficiency. Methodological procedures ensuring selectivity in staffing, performance-based remuneration, engagement and better employee opportunities lead to a higher level of organizational efficiency [21,22]. The efforts to reconcile employee and organization values are reflected in an overall comparison and adaptation of specific values such as access to work, improvements or social initiatives of the organization. In building future-oriented employee relationships, organizations anticipate the presence of vacancies and the possibilities of filling them in different procedures before they occur [23]. Human resource practices at organizational level can affect employee attitudes [3] as well as fluctuation and turnover of employees [24].

The importance of sustainable development in our society is steadily increasing, so it is also important in research, to develop the paradigm of sustainable development of human resources [25]. The integration concept of sustainable human resource management, aimed at reconciling competitiveness, responsibility towards oneself, the environment and social responsibility, assumes that organizations, employees and society are responsible for the sustainability of operations [26]. Human resource management practices are usually monitored in terms of management practices, paying little attention to employees, therefore, factors related to employees, such as motivation, and their skills and potential should also be considered. Increasing levels of job satisfaction and performance can be achieved when human resource management consider also factors related to employees [27].

When the management of organizations implements human resource management practices, they increase the employability of employees. The implemented human resources procedures to improve employee motivation and skills also increase satisfaction with current employability of employees and increase organizational productivity [28]. In order to make the best use of human potential in the enterprise, it is necessary that the efficiency of human resource management is translated into performance measures [29]. Assessment of employee performance is an important element of human resource management [30]. For performance appraisal related to the specific job position are important assessments based on behavior that is a manifestation of achieved level of competencies required [31,32]. Strengthening the culture of education and development reinforces the motivation to transfer knowledge into practice [33].

Based on the above, the functional model in Figure 1 illustrates the interconnection of education (development), motivation, and performance of employees as interconnected and interacting areas of 
human resource management, considering employees' competencies and developing their potential. Motivation influences the success of education and efficiency in achieving performance. Education and performance increase employee motivation and thus the effort to perform. Education (development) and motivation are fundamental preconditions for employee performance. However, employee competencies can only be developed within the limits set by the employee's potential. Sustainable human resource management should focus mainly on exploiting, developing and maintaining the potential of employees. Such a holistic approach to human resource management will enable employees to be involved in all areas of sustainable development, economic, environmental and social through enhancing their commitment and engagement.

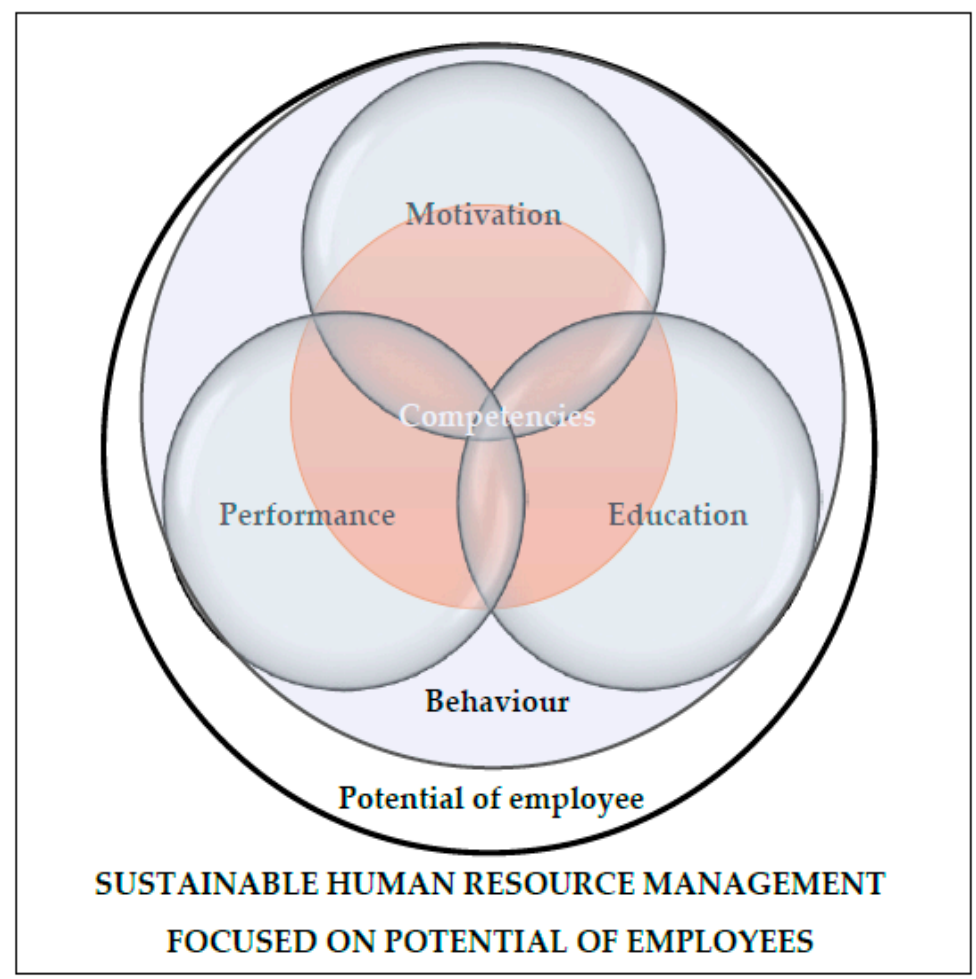

Figure 1. Functional model of sustainable human resource management (Source: own elaboration, 2019).

Figure 1 shows that the functional model is in line with sustainable human resource management which aims to manage human resources in a sustainable way [34]. Given the importance of human resource management practices for the business performance of enterprises, efforts should be made to adequately adapt and implement human resource management practices in order to improve the performance of enterprises.

Demographic evolution as well as many studies in this field $[28,35,36]$ point out that organizations must cope with an aging workforce. In addition, several generations of employees meet at the workplace. Each of them manifests typical attitudes to work, values, and motivational preferences $[37,38]$. That is why it is important to consider the structure and diversity of the workforce in the organization when managing the organization's human resources, and especially in areas such as performance management. The term 'generation' can be understood as a group of people or a cohort which have common years of birth and also some experience as they live in the same time period [39].

The generation of Veterans, named also as Silent Generation, Seniors, Matures, or Builders, consists from people born in 1925-1945. Some social, cultural, political, and economic affairs are the main events that members of this generation abided in their lives and formed their personal characteristics. Wars and economy hardships are the main events traditionalists suffered as they lived a substantial part of their lives under their consequences. Most of their features are influenced by these sufferings. That is why conservative traditionalists, who want to protect and lead a modest life without spending much, 
and they need stability. Permanent work and financial security are essential for these people. They prefer security and authority [40]. Members of this generation are currently in the labor market only in exceptional and specific professions, but their approach to work has influenced future generations of employees [41].

The post-war generation of people is a generation also known as Baby Boomers, born in 1946-1960. This generation was required to perform tasks at work and the ambition or initiative was perceived as an obstacle. The rush to work was not caused by enthusiasm but by the necessity to arrive on time, while workers were supervised to ensure that they did not damage or steal property. Work was an essential part of life and not a way of job satisfaction [42]. Baby boomers expect that the experience and expertise they bring to the workplace and to the work teams will be respected [43]. Sometimes they are considered individualistic and selfish, unwilling to retire [44].

Employees belonging to Generation X, born in 1961-1980, expect career development from work, although it is not necessarily straightforward, and growth. They want to have a life beyond work, expecting recognition of individualized pay and flexible working time $[43,45,46]$. They care for themselves and do not want to be dependent on anyone [47]. They are more committed to people than organizations [48]. They formed a circle of friends with whom they were in contact when they parents were at work. Although they consider themselves individualists, they are very dependent on the support and assessment of their friends [49]. However, the high demands of others may endanger long-term relationships and increase the need for autonomy [50]. Many of the Generation X members are afraid of being dismissed and fear that they will lose their jobs [41].

Generation Y, born in 1981-1995, is considered as a mobile generation. It is therefore an advantage for them if they can return after they leave the employer [51]. Lack of incentives makes them reluctant to retain and stay with the employer [52]. Employees from this generation expect stability from the employer and are characterized by high expectations. If they are not fulfilled, they only do what they are paid for and do not intend to remain with the employer, seeking new employment opportunities to find new and better jobs [53]. Generation $Y$ members are very social and appreciate friendship and personal relations. They like to work in teams and with their friends. They are noisy at work and enjoy working in a friendly atmosphere, so their teamwork seems like social event [37-54].

The members of generation born in 1996-2009 are referred to as the Generation Z. The Generation $Z$ is increasingly concerned about the environment. Increasing interest in the environment is caused by increasing environmental awareness, which, however, varies according to their level of interest in environmental issues and sustainability behaviors [55]. The influence or pressure of peers affects their behavior [56]. The members of the Generation $\mathrm{Z}$ prove to be more independent of their colleagues and thus much more dependent on their own abilities and competencies. They may but must not to share their same generational belonging with their co-workers [57]. In addition to the opportunity for self-realization and meaningful work they expect to have team of friendly colleagues [58].

It may be challenging for employers to find ways how to attract, manage and retain young talent. The key is to know their individual preferences and needs to know how to meet their expectations [59]. The young generation is becoming a challenge for employers because as they tend to change employers. This negative trend in Slovakia is reinforced by the migration of the young generation abroad [60]. The employers will have to consider the interests and needs of Generation $\mathrm{Z}$ beyond financial compensation such as open communication, fair action, and flexibility in employment or social responsibility. Employees of this generational group also appreciate mentoring [61]. They like a feeling of freedom when possible, but they also appreciate the willingness to provide guidance [62]. Generations $Y$ and $\mathrm{Z}$ are sometimes collectively referred to as Millennials. The millennials are recognized as enjoyable collaborators and shared values are more important to them for the perception of meaningful work than to older generations [63]. 
The inclusion of an individual in a very cohesive work group affects employee satisfaction with different work aspects $[64,65]$. This has implications for working behavior. A demographic age study showed, if employees differ in age from the working group, that it lowers the level of integration in the workgroup and increases employees' retirements [66]. Therefore, it is important to investigate perceived relationships in the workplace, also regarding the age diversity.

Research Hypothesis 1: There is a statistically significant difference between various generational groups of employees in the perceived relationships among employees.

Managers and leaders of organizations and enterprises do not have to cope only with aging employees and new attitudes and approaches to work. What they also must face is recruitment, efficient utilization, and retention of the workforce. The ability to cope with these challenges through efficient human resource management in all areas of sustainable development has significant implications for the existence of enterprise in the future. Moreover, demonstrating the responsibility of organizations in the sustainability field should have a side positive effect. Even a slight reduction in employee fluctuation and turnover can pay off in general, especially for key employees. It is important for enterprises to see how employees are involved and integrated into the work teams and collectives [67].

There may seem to be little real evidence that human resources policies and practices are improving the performance of the organization. However, the evidence continues to grow and, although it takes a long time for long-term data to exist, the evidence is consistent with the view that human resources policies and practices within the organization have a strong impact on employee motivation to manifest the different attitudes and behaviors needed to support and implement organization strategies [68]. All employees themselves are sometimes overlooked as a source of sustainable competitive advantage as their benefits to the enterprises are less visible. Nevertheless, these employees can play an important role in creating a competitive advantage as they directly influence the production of a product or service. Teams or collectives of employees manifest various social complexity (good co-working relations, trust, etc.) that could not be imitable, but beneficial for involved employees. Consequently, it can be concluded that usually they are top managers or specialists, who are clearly valuable. These employees and can provide visible competitive advantage, but usually a short-term a sustainable competitive advantage should be more probably to be found across the whole human resources and their potential [69].

Not only formal but also informal relationships are important for the effectiveness of the working collectives. Informal relationships are an extrapolation of formal relationships. However, informal relationships support formal relationships. Moreover, it was confirmed, that relations between employees greatly affect the coherence of working teams [70]. Interaction with other people can be a source of conflict, stress, but also support. Bad relationships include low confidence, low support, and low interest in listening or dealing with problems [71]. Working groups' coherence, conflict rates and their impact on work performance and achievement are also influenced by cultural aspects [72,73]. However, scientific studies have pointed to the impact of conflicts in the workplace as well as in the life beyond work $[74,75]$. The degree to which individual employees perceive that they are expected to manifest the desired positive emotions and suppress negative emotions at work is a catalyzer for burnout. The degree of conflict at work also affects conflicts between work and family life [75]. Social support from a supervisor or colleagues allows reducing the impact of workplace stress that affects performance degradation [76]. Socializing newly recruited employees allows them to be integrated into the collective and reduces fluctuation and employees' turnover. The inclusion of new employees in the team increases integration in employment and active involvement of employees [77]. Sustainable human resource management is seen as a way to, among other things, ensure enterprises to attract and retain talented employees, maintain employees, invest in the skills of employees on a long-term basis, manage aging workforces, and create sustained employee relationships [78]. 
For newly hired employees and their retention in work, it is important to learn how to do work (recognized as conscientiousness) [38], but also to meet the 'right' people from whom they can learn about the organization processes and so enable their job embeddedness. This will ensure not only lower turnover in the early stages of employee adaptation and performance assurance. It is confirmed that people decided to stay in the enterprise are more efficient and provide higher performance [79]. Colleagues and superiors contribute to creating a social working environment. A pleasant and healthy work environment has a positive impact on direct impact on work efficiency and employees' performance [80-82]. Increasing satisfaction with co-workers also increases pro-social behavior towards co-workers, which benefit not only for co-workers, but also for the organizations themselves [83]. Relationships between employees with each other and supervisors and employees affect performance in a different way through the perception of both, information and interpersonal justice. The quality of relationships between employees and co-workers further enhances work performance by motivating employees to engage in learning and sharing knowledge [84]. Employees are more personally interested in the welfare of the organizations in which they work and are more motivated to contribute to collective success if they have more positive relationship to their co-workers [85]. Supportive behavior by supervisors and assistance from co-workers mutually interact and enable individuals to face high work pressure. The interaction of this support is crucial to avert the threat of loss of employees in the organization [86]. Based on this, we hypothesized that relationships with co-workers and lowest turnover of employees are in positive relation.

Research Hypothesis 2: There is a statistically significant relation between the perceived relationships among employees and perceived organizational ability to retain important employees.

Figure 2 shows the logic of the formulated research hypothesis 2 . The social working environment of an organization is created by formal, informal as well as symmetric and asymmetric relationships. Asymmetrical relationships result from vertical organizational management structures within an organization (they represent management relationships with other employees), which may not be only the relationship between the direct supervisor and the employee. Symmetric relationships can be understood as relationships between employees at the same level of organizational hierarchy. Demonstrating the existence of a statistically significant relation between relationships among employees and the ability to retain important employees can provide the information needed in a human resource management system with an emphasis on the stabilization of organization's employees.

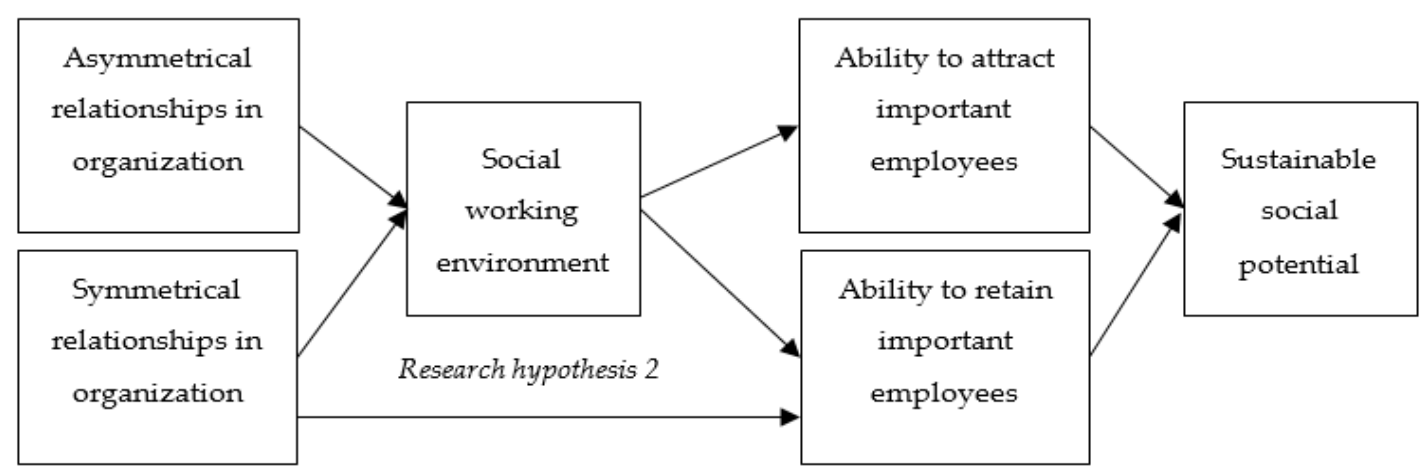

Figure 2. Mediated effect of workplace relationships on sustainable social potential creation in organization (Source: own elaboration, 2019).

Organizational ability to attract and retain important employees is precondition for creation the sustainable social potential of the enterprise (Figure 2). Such potential enables the management of enterprises to support desirable behaviors and to form positive relationships in organization through targeted activities in sustainable human resource management. 


\section{Materials and Methods}

The main aim of the research was to examine the perceived organizational performance and human resource management practices that are focused on the recruiting and retention of staff and their perception with respect to different generations of employees.

In order to fulfill the main aim of the research we have determined two research questions and formulated two research hypotheses. Initially, research questions were set out to frame and address the research problem. Afterwards, we defined research hypotheses to answer our research questions. The research hypotheses are formulated in the previous part of the paper following the theoretical background. The research questions and hypotheses were defined based on analysis and synthesis of theoretical knowledge, scientific studies and experiments, and based on the authors' practical experience in human resource management area.

Research Question 1: How do employees at different job positions perceive the ability of their organization to attract and retain important employees?

Research Question 2: How do employees from different generational groups perceive relationships between managers and other employees and relationships among employees in general in their organization?

The research sample consisted of employees of industrial enterprises operating in the Slovak Republic. For better representativeness of the sample, we decided to include into the research sample employees employed in industrial enterprises of all sizes and members of all generational employees' groups present in the labor market. Respondents were addressed personally by authors and voluntary data collectors, and questionnaires were distributed exclusively in paper form. Subsequently, the collected data were processed in Microsoft Excel. Overall, $\mathrm{N}=1471$ respondents (employees of industrial enterprises) participated in the research. The distribution of the respondents by date of birth in absolute frequency of answers is shown in the Figure 3.

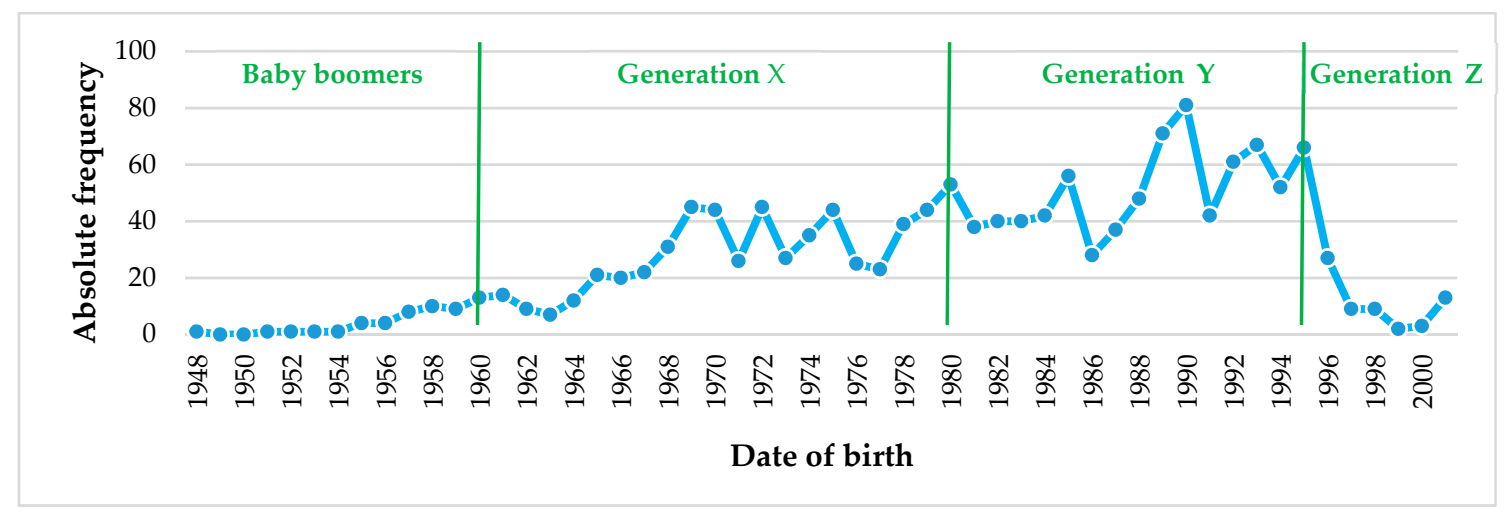

Figure 3. Distribution of respondents by date of birth (Source: own elaboration, 2019).

The Figure 3 shows that respondents born in 1988-1990 are the largest group, the next largest group are the respondents born in 1992-1996. The authors of the paper have respondents (employees of industrial enterprises) from different generational groups (Baby boomers born in 1946-1960; Generation Y born in 1961-1980; Generation X born in 1981-1995 and Generation Z born in 1996-2010). The absolute and relative frequency of the respondents classified into individual generational groups are shown in the Table 1. 
Table 1. Distribution of respondents by generational groups (Source: own elaboration, 2019).

\begin{tabular}{ccc}
\hline Generation & Absolute Frequency & Relative Frequency [\%] \\
\hline Baby boomers & 52 & 3.54 \\
Generation X & 586 & 39.84 \\
Generation Y & 770 & 52.35 \\
Generation Z & 50 & 3.39 \\
No answer & 13 & 0.88 \\
Total & 1471 & 100.00 \\
\hline
\end{tabular}

In Table 1 it is shown the generational structure of respondents by classification to their appropriate generational group. The data in the table shows that the respondents belonging to the Generation $X(39.84 \%)$ and $Y(52.35 \%)$ have the largest representation. The above results also reflect the current representation of the working population in the Slovak Republic in recent years. Some respondents did not answer the question concerning the date of birth, but these respondents answered other items of the questionnaire, and therefore were included in the group without answers (13). The following Table 2 shows all respondents distribution by job classification.

Table 2. Distribution on respondents by job classification (Source: own elaboration, 2019).

\begin{tabular}{ccc}
\hline Job Classification & Absolute Frequency & Relative Frequency [\%] \\
\hline Production employee & 549 & 37.32 \\
Administrative employee & 631 & 42.90 \\
Managing employee & 272 & 18.49 \\
No answer & 19 & 1.29 \\
Total & 1471 & 100.00 \\
\hline
\end{tabular}

The Table 2 shows that administrative employees have the largest representation from all analyzed respondents $(42.90 \%)$, the next largest group are production employees, who accounted for 549 of 1471 respondents $(37.32 \%)$. The respondents working in managing positions have the lowest representation $(18.49 \%)$. Some respondents did not answer the question concerning the job classification, but these respondents answered other items of the questionnaire, and therefore were included in the group without answers (19).

For the purpose of data collection was constructed valid collection tool (the research questionnaire). Socio-demographic questions and questions relating to perceived organizational performance were used to construct the research questionnaire. Socio-demographic questions related the territorial scope of organization, the number of employees in the organization, gender, job classification, and date of birth of the respondents. For questions regarding the perceived organizational performance, respondents could choose as an option following answers: much worse, worse, better, much better. The reliability of the data collection tool in terms of the internal consistency of the questionnaire was carried out by calculating the Cronbach's coefficient alpha. For items relating to the perceived organizational performance, the Cronbach's coefficient alpha reached a level of 0.85 therefore we can say that the data collection tool is sufficient for scientific purpose [87].

The distribution of the data collection tool (the research questionnaire) and the creation of the research sample were selected through multi-stage random conglomerate sampling. The questionnaire was distributed directly to employees of industrial enterprises in paper form to ensure interaction with the respondents and familiarization with the way of completing individual items of the research questionnaire. Data collection was carried out from September 2018 to January 2019. During the processing of the results, the anonymity of individual respondents was preserved.

To evaluate the collected data, the authors of the paper used the methods of descriptive statistical analysis, the results were interpreted in the form of tables (cross-tables, tables of absolute and relative frequencies and supplementary tables of statistical test results) and in the form of graphical 
representation (polygon). The data collected were processed in Microsoft Excel. Furthermore, non-parametric statistical tests were used to identify the statistically significant differences and relationships between the selected dependent and independent variables. Namely there were used the following tests: Pearson's chi-squared test or Chi-squared test and Spearman's rho correlation coefficient. The abovementioned statistical tests were conducted to evaluate the determined research hypotheses in the IBM SPSS 22.0 (Statistical Package for the Social Sciences). The significance level was significant at a 0.01 (significance level $\alpha=1 \%$ ) level. It follows that the obtained and interpreted results can be considered statistically significant. The basic thought processes such as comparison, analysis, synthesis, abstraction, generalization and deduction were used in all parts of the paper (from introduction to discussion).

\section{Research Results}

The following part of the paper is divided into two partial sections. The first one is focused on evaluation and interpretation of the determined research questions. The second one contains the results of testing research hypotheses defined.

\subsection{Results for Research Questions}

As mentioned above, different variables can be identified to analyze perceived organizational performance in area of sustainable human resource management. The authors of the paper have focused on the field of organizational performance which is closely related to organizational culture and interpersonal relationships.

Research question 1: How do employees in different job positions perceive the ability of their organization to attract and retain important employees?

Within the research area framed by the first research question, there were two chosen variables, which are primary preconditions for human potential development, internal motivation and consecutive the job performance of employees. The first variable is the ability to attract important new employees, which is perceived differently by various generations of employees. The results can be seen in Table 3 .

Table 3 shows that the most critical (much worse) perceived organizational ability to attract new employees is the production employees $(14.75 \%)$, followed by administrative employees $(10.30 \%)$. The ability to attract new employees to the organization also production employees $(42.81 \%)$ perceive as worse, followed by administrative employees (38.51\%). On the other hand, respondents at managerial positions perceive organizational ability as much better (14.34\%), followed by administration $(13.15 \%)$. The ability to attract important newcomers was indicated as better by respondents at managerial positions $(41.18 \%)$, followed by administration $(37.08 \%)$. The research results proved that employees at various work positions perceive this organizational performance variable differently (values are highlighted in Table 3).

The second part of the first research question deals with perceived organizational performance variable, namely the ability to retain important employees. We decided to examine the view differentiated with respect to different positions of employees (production, administrative, and managerial staff). This item is closely linked to the performance given due to the motivation and the hierarchy of needs. If the employee does not feel recognized and is not informed how valued his/her contribution is, his/her internal motivation decreases, and the work performance is reduced. The results for perceived organizational ability to retain important employees can be seen in Table 4 . 
Table 3. Perceived ability to attract new employees by different job positions (Source: own elaboration, 2019).

\begin{tabular}{|c|c|c|c|c|c|c|c|c|c|c|}
\hline \multicolumn{11}{|c|}{ The Ability to Attract New Employees } \\
\hline \multirow{2}{*}{ Scale/Position } & \multicolumn{2}{|c|}{ Production } & \multicolumn{2}{|c|}{ Administrative } & \multicolumn{2}{|c|}{ Management } & \multicolumn{2}{|c|}{ No Answer } & \multicolumn{2}{|c|}{ Sum } \\
\hline & $\begin{array}{l}\text { Relative } \\
\text { Frequency }\end{array}$ & $\begin{array}{l}\text { Absolute } \\
\text { Frequency }\end{array}$ & $\begin{array}{l}\text { Relative } \\
\text { Frequency }\end{array}$ & $\begin{array}{l}\text { Absolute } \\
\text { Frequency }\end{array}$ & $\begin{array}{l}\text { Relative } \\
\text { Frequency }\end{array}$ & $\begin{array}{l}\text { Absolute } \\
\text { Frequency }\end{array}$ & $\begin{array}{l}\text { Relative } \\
\text { Frequency }\end{array}$ & $\begin{array}{l}\text { Absolute } \\
\text { Frequency }\end{array}$ & $\begin{array}{l}\text { Relative } \\
\text { Frequency }\end{array}$ & $\begin{array}{l}\text { Absolute } \\
\text { Frequency }\end{array}$ \\
\hline Much worse & 14.75 & 81 & 10.30 & 65 & 8.09 & 22 & 10.53 & 2 & 11.56 & 170 \\
\hline Worse & 42.81 & 235 & 38.51 & 243 & 36.03 & 98 & 21.05 & 4 & 39.43 & 580 \\
\hline Better & 34.97 & 192 & 37.08 & 234 & 41.18 & 112 & 36.84 & 7 & 37.05 & 545 \\
\hline Much better & 6.56 & 36 & 13.15 & 83 & 14.34 & 39 & 31.58 & 6 & 11.15 & 164 \\
\hline No answer & 0.91 & 5 & 0.95 & 6 & 0.37 & 1 & 0.00 & 0 & 0.82 & 12 \\
\hline Total & 100.00 & 549 & 100.00 & 631 & 100.00 & 272 & 100.00 & 19 & 100.00 & 1471 \\
\hline
\end{tabular}

Table 4. Perceived ability to retain important employees by job positions (Source: own elaboration, 2019).

\begin{tabular}{|c|c|c|c|c|c|c|c|c|c|c|}
\hline \multicolumn{11}{|c|}{ The Ability to Retain Important Employees } \\
\hline \multirow[b]{2}{*}{ Scale/Position } & \multicolumn{2}{|c|}{ Production } & \multicolumn{2}{|c|}{ Administrative } & \multicolumn{2}{|c|}{ Management } & \multicolumn{2}{|c|}{ No Answer } & \multicolumn{2}{|c|}{ Sum } \\
\hline & $\begin{array}{l}\text { Relative } \\
\text { Frequency }\end{array}$ & $\begin{array}{l}\text { Absolute } \\
\text { Frequency }\end{array}$ & $\begin{array}{l}\text { Relative } \\
\text { Frequency }\end{array}$ & $\begin{array}{l}\text { Absolute } \\
\text { Frequency }\end{array}$ & $\begin{array}{l}\text { Relative } \\
\text { Frequency }\end{array}$ & $\begin{array}{l}\text { Absolute } \\
\text { Frequency }\end{array}$ & $\begin{array}{l}\text { Relative } \\
\text { Frequency }\end{array}$ & $\begin{array}{l}\text { Absolute } \\
\text { Frequency }\end{array}$ & $\begin{array}{l}\text { Relative } \\
\text { Frequency }\end{array}$ & $\begin{array}{l}\text { Absolute } \\
\text { Frequency }\end{array}$ \\
\hline Much worse & 10.02 & 55 & 10.62 & 67 & 5.15 & 14 & 0.00 & 0 & 9.25 & 136 \\
\hline Worse & 41.17 & 226 & 32.81 & 207 & 31.99 & 87 & 36.84 & 7 & 35.83 & 527 \\
\hline Better & 38.43 & 211 & 38.99 & 246 & 43.02 & 117 & 42.11 & 8 & 39.56 & 582 \\
\hline Much better & 9.47 & 52 & 16.32 & 103 & 19.49 & 53 & 15.79 & 3 & 14.35 & 211 \\
\hline No answer & 0.91 & 5 & 1.27 & 8 & 0.37 & 1 & 5.26 & 1 & 1.02 & 15 \\
\hline Total & 100.00 & 549 & 100.00 & 631 & 100,00 & 272 & 100.00 & 19 & 100.00 & 1471 \\
\hline
\end{tabular}


The Table 4 shows that employees at different positions differently perceive the variable ability to retain important employees. Administrative employees consider the worst ability to retain employees in the organization in which they work. Production employees perceive the ability to retain important employees worse. It has been unequivocally shown to the management that when comparing the perceived ability to retain important employees among different jobs, it is the management that they consider to be better and much better. This was influenced by the fact that it is the management that makes decisions about the importance of various positions within the organization. If we do not compare the results by the job positions, it can be declared that a total of 663 respondents $(45.08 \%)$ perceive that industrial enterprises they work for are worse in their ability to retain important employees, compared to similar organizations. On the other hand, up to 793 respondents (53.91\%) perceive that industrial enterprises they work for can retain important employees.

Research Question 2: How do employees from different generational groups perceive relationships between managers and other employees and relationships among employees in general in their organization?

The second research question was focused on perceived relationships within organization. The first analyzed variable of perceived organizational performance was the relationships between managers and other employees. The abovementioned variable has a great influence on the performance of employees. Inner well-being or employee discomfort often depends on relationships at the workplace within vertical structures. If the employees are treated well and manager use appropriate leadership style, he/she can create an ambient working atmosphere and the performance of employees is higher than otherwise. The results of the examination of the relationships between managers and other employees are differentiated by various generational groups of employees can be seen in Table 5 .

It can be seen from Table 5 that the results are differentiated according to the respondents' belonging to individual generational groups (highlighted values). In the generation of Baby Boomers, the largest group of respondents think that relationships between managers and employees are within their organization they work for better, but at the same time the second most common answer is that they are worse compared to other organizations. The answers are similar in Generation $X$, and it is Generation $X$ that most often indicated that relationships are worse compared to other generational groups. The members of Generation $Y$, most frequently respond that relationships are better and then worse similarly than in the previous two groups. However, no option is the most numerous in comparison with other generations of employees. The distribution of answers among Generation $\mathrm{Z}$ members is similar as in other generational groups. Therefore, the most frequently response answer within the generational group is the better and then the option worse. When comparing all generations, it is the Generation $Z$ that regards workplace relationships much better and much worse than other generations. It follows from analyzed results that perception of relationships between managers and other employees among various generations is very similar but in comparative analysis between all generations we find that the analyzed variable is perceived differently between different generations. This implies that age is the factor that influences different perceptions of variables of perceived organizational performance.

The last variable to be examined in perceived organizational performance is the relationship between employees in general. We suppose that this factor is determining for employee work behavior and strongly influences the decision-making about keeping or leaving the job. We also suppose that workplace relations affect the performance of employees due to that positive workplace relationships facilitate mutual help and support from colleagues and negative relationships caused absenteeism and fluctuation in effort to avoid unpleasant working surrounding. The research results analysis for this variable can be seen in Table 6 below. 
Table 5. Perceived relationships between managers and other employees by different generational groups (Source: own elaboration, 2019).

\begin{tabular}{|c|c|c|c|c|c|c|c|c|c|c|c|c|}
\hline \multicolumn{13}{|c|}{ Relationships between Managers and Other Employees } \\
\hline \multirow[b]{2}{*}{ Scale/Generation } & \multicolumn{2}{|c|}{ Baby Boomers } & \multicolumn{2}{|c|}{ Generation $X$} & \multicolumn{2}{|c|}{ Generation $\mathrm{Y}$} & \multicolumn{2}{|c|}{ Generation $\mathrm{Z}$} & \multicolumn{2}{|c|}{ N/A } & \multicolumn{2}{|c|}{ Sum } \\
\hline & $\begin{array}{c}\text { Relative } \\
\text { Frequency }\end{array}$ & $\begin{array}{l}\text { Absolute } \\
\text { Frequency }\end{array}$ & $\begin{array}{c}\text { Relative } \\
\text { Frequency }\end{array}$ & $\begin{array}{l}\text { Absolute } \\
\text { Frequency }\end{array}$ & $\begin{array}{c}\text { Relative } \\
\text { Frequency }\end{array}$ & $\begin{array}{l}\text { Absolute } \\
\text { Frequency }\end{array}$ & $\begin{array}{c}\text { Relative } \\
\text { Frequency }\end{array}$ & $\begin{array}{c}\text { Absolute } \\
\text { Frequency }\end{array}$ & $\begin{array}{c}\text { Relative } \\
\text { Frequency }\end{array}$ & $\begin{array}{l}\text { Absolute } \\
\text { Frequency }\end{array}$ & $\begin{array}{c}\text { Relative } \\
\text { Frequency }\end{array}$ & $\begin{array}{l}\text { Absolute } \\
\text { Frequency }\end{array}$ \\
\hline Much worse & 5.77 & 3 & 6.48 & 38 & 5.06 & 39 & 10.00 & 5 & 15.38 & 2 & 5.91 & 87 \\
\hline Worse & 34.62 & 18 & 35.49 & 208 & 32.08 & 247 & 28.00 & 14 & 23.08 & 3 & 33.32 & 490 \\
\hline Better & 50.00 & 26 & 44.72 & 262 & 43.90 & 338 & 40.00 & 20 & 53.85 & 7 & 44.39 & 653 \\
\hline Much better & 9.61 & 5 & 12.46 & 73 & 17.79 & 137 & 22.00 & 11 & 7.69 & 1 & 15.43 & 227 \\
\hline No answer & 0.00 & 0 & 0.85 & 5 & 1.17 & 9 & 0.00 & 0 & 0.00 & 0 & 0.95 & 14 \\
\hline Total & 100.00 & 52 & 100.00 & 586 & 100.00 & 770 & 100.00 & 50 & 100.00 & 13 & 100.00 & 1471 \\
\hline
\end{tabular}

Table 6. Perceived relationships between employees by different generational groups (Source: own elaboration, 2019).

\begin{tabular}{|c|c|c|c|c|c|c|c|c|c|c|c|c|}
\hline \multicolumn{13}{|c|}{ Relationships between Managers and Other Employees } \\
\hline \multirow[b]{2}{*}{ Scale/Generation } & \multicolumn{2}{|c|}{ Baby Boomers } & \multicolumn{2}{|c|}{ Generation $\mathrm{X}$} & \multicolumn{2}{|c|}{ Generation $Y$} & \multicolumn{2}{|c|}{ Generation Z } & \multicolumn{2}{|c|}{ N/A } & \multicolumn{2}{|c|}{ Sum } \\
\hline & $\begin{array}{l}\text { Relative } \\
\text { Frequency }\end{array}$ & $\begin{array}{l}\text { Absolute } \\
\text { Frequency }\end{array}$ & $\begin{array}{l}\text { Relative } \\
\text { Frequency }\end{array}$ & $\begin{array}{l}\text { Absolute } \\
\text { Frequency }\end{array}$ & $\begin{array}{c}\text { Relative } \\
\text { Frequency }\end{array}$ & $\begin{array}{l}\text { Absolute } \\
\text { Frequency }\end{array}$ & $\begin{array}{l}\text { Relative } \\
\text { Frequency }\end{array}$ & $\begin{array}{l}\text { Absolute } \\
\text { Frequency }\end{array}$ & $\begin{array}{l}\text { Relative } \\
\text { Frequency }\end{array}$ & $\begin{array}{l}\text { Absolute } \\
\text { Frequency }\end{array}$ & $\begin{array}{l}\text { Relative } \\
\text { Frequency }\end{array}$ & $\begin{array}{l}\text { Absolute } \\
\text { Frequency }\end{array}$ \\
\hline Much worse & 5.77 & 3 & 5.63 & 33 & 3.38 & 26 & 10.00 & 5 & 15.38 & 2 & 4.69 & 69 \\
\hline Worse & 25.00 & 13 & 29.69 & 174 & 19.74 & 152 & 20.00 & 10 & 15.38 & 2 & 23.86 & 351 \\
\hline Better & 53.85 & 28 & 48.64 & 285 & 54.93 & 423 & 48.00 & 24 & 61.55 & 8 & 52.21 & 768 \\
\hline Much better & 15.38 & 8 & 15.19 & 89 & 21.17 & 163 & 22.00 & 11 & 7.69 & 1 & 18.49 & 272 \\
\hline No answer & 0.00 & 0 & 0.85 & 5 & 0.78 & 6 & 0.00 & 0 & 0.00 & 0 & 0.75 & 11 \\
\hline Total & 100.00 & 52 & 100.00 & 586 & 100.00 & 770 & 100.00 & 50 & 100.00 & 13 & 100.00 & 1471 \\
\hline
\end{tabular}


Based on the comparative analysis of data found in Table 6, it can be assumed that the perception of workplace relations between employees is generally different from the point of view of the various generations of employees in industrial enterprises. If the relations with other employees were perceived much worse, the largest part of respondents was from generation Baby Boomers. Generation X perceives the workplace relationships as worse. On the other hand, Generation Y respondents consider workplace relationships as better compared to other organizations. Employees from Generation $\mathrm{Z}$ identified relationships at the workplace as much better.

\subsection{Results for Research Hypotheses}

Age diversity influences perceived organizational performance issues, as confirmed the results for research questions. Thus, we could approach to testing the research hypotheses.

Research Hypothesis 1: There is a statistically significant difference between various generational groups of employees in the perceived relationships among employees.

After testing the hypothesis 1, the difference between different generations of employees and relationship between employees in general was confirmed. The results of these variables can be seen in Table 7 shown below.

Table 7. Perceived relationships with other employees by different generational groups (Source: own elaboration, 2019).

\begin{tabular}{cccccc}
\hline \multirow{2}{*}{ Cross Table } & \multicolumn{3}{c}{ Relationships with Other Employees } & \multirow{2}{*}{ Total } \\
\cline { 2 - 4 } & Much Worse & Worse & Better & Much Better & \\
\hline \multirow{2}{*}{ Baby boomers } & 3 & 13 & 28 & 8 & 52 \\
& $5.8 \%$ & $25.0 \%$ & $53.8 \%$ & $15.4 \%$ & $100.0 \%$ \\
Generation X & 33 & 174 & 285 & 89 & 581 \\
Generation $\mathrm{Y}$ & $5.7 \%$ & $29.9 \%$ & $49.1 \%$ & $15.3 \%$ & $100.0 \%$ \\
& 26 & 152 & 423 & 163 & 764 \\
Generation $\mathrm{Z}$ & $3.4 \%$ & $19.9 \%$ & $55.4 \%$ & $21.3 \%$ & $100.0 \%$ \\
& 5 & 10 & 24 & 11 & 50 \\
Total & $10.0 \%$ & $20.0 \%$ & $48.0 \%$ & $22.0 \%$ & $100.0 \%$ \\
\hline
\end{tabular}

From Table 7 it is apparent that the perceived relationships in the workplace are perceived differently by various generational groups of employees. It follows that we can assume a statistical difference between the monitored variables. To evaluate the hypothesis of the research was carried out statistical test Pearson chi-Square, the outcome of which can be seen in the Table 8.

Table 8. Chi-Square tests of relationships to other employees across generational groups (Source: own elaboration, 2019).

\begin{tabular}{cccc}
\hline Chi-Square Tests & Value & df & Asymp. Sig. (2-Sided) \\
\hline Pearson Chi-Square & 31.027 & 9 & 0.000 \\
Likelihood Ratio & 30.328 & 9 & 0.000 \\
Linear-by-Linear Association & 15.166 & 1 & 0.000 \\
N of Valid Cases & 1447 & - & - \\
\hline
\end{tabular}

Based on the research results, it can be argued that there is a statistically significant difference $(p<$ 0.001 ) between all four generations of employees in the perception of employees' relationships with each other, as shown in Table 8 above. In order to specify the difference, a correlation analysis was also carried out, the results can be seen in Table 9 below. 
Table 9. Correlations: Spearman's rho for relationships to other employees across generational groups (Source: own elaboration, 2019).

\begin{tabular}{lcc}
\hline \multicolumn{2}{c}{ Correlations-Spearman's rho } & $\begin{array}{c}\text { Relationships to Other } \\
\text { Employees in General }\end{array}$ \\
\hline & Correlation Coefficient & $0.118^{* *}$ \\
Generational groups of employees & Sig. (2-tailed) & 0.000 \\
& $\mathrm{~N}$ & 1447 \\
\hline
\end{tabular}

** Correlation is significant at the 0.01 level (2-tailed).

As can be seen in Table 9, there is a statistically significant relationship between selected generations and perceived relationships between employees in general. A weak correlation which is statistically significant (Spearman's rho $=0.118 ; p<0.001$ ) can be observed. This significant relationship can be expressed in the following way: the younger the employee, the better his/her perception of the evaluated item. Based on the analyzed data in Tables 8 and 9, it can be concluded that the first research hypothesis can be confirmed, and it can be argued that there is a statistically significant difference in the perception of this item between different generations of employees.

Research Hypothesis 2: There is a statistically significant relation between the perceived relationships among employees and perceived organizational ability to retain important employees.

The second research hypothesis supposes the statistical relationship between the perceived variables of organizational performance declared by positive relationships between employees in general and the ability to retain important employees. A pairwise comparison of selected variables can be seen in Table 10, in a cross-table interpretation form.

Table 10. Perceived relationships between employees and perceived ability to retain important employees (Source: own elaboration, 2019).

\begin{tabular}{|c|c|c|c|c|c|c|}
\hline \multirow{2}{*}{\multicolumn{2}{|c|}{$\begin{array}{c}\text { Cross Table-Perceived } \\
\text { Organizational Performance }\end{array}$}} & \multicolumn{4}{|c|}{ Perceived Relationships between Employees } & \multirow{2}{*}{ Total } \\
\hline & & Much Worse & Worse & Better & Much Better & \\
\hline \multirow{8}{*}{$\begin{array}{l}\text { Perceived ability to } \\
\text { retain an important } \\
\text { employee }\end{array}$} & \multirow{2}{*}{ Much worse } & 32 & 50 & 45 & 9 & 136 \\
\hline & & $23.5 \%$ & $36.8 \%$ & $33.1 \%$ & $6.6 \%$ & $100.0 \%$ \\
\hline & \multirow{2}{*}{ Worse } & 23 & 179 & 269 & 54 & 525 \\
\hline & & $4.4 \%$ & $34.1 \%$ & $51.2 \%$ & $10.3 \%$ & $100.0 \%$ \\
\hline & \multirow{2}{*}{ Better } & 8 & 99 & 346 & 128 & 581 \\
\hline & & $1.4 \%$ & $17.0 \%$ & $59.6 \%$ & $22.0 \%$ & $100.0 \%$ \\
\hline & \multirow{2}{*}{ Much better } & 5 & 20 & 106 & 78 & 209 \\
\hline & & $2.4 \%$ & $9.6 \%$ & $50.7 \%$ & $37.3 \%$ & $100.0 \%$ \\
\hline \multicolumn{2}{|l|}{ Total } & $\begin{array}{c}68 \\
47 \%\end{array}$ & $\begin{array}{c}348 \\
240 \%\end{array}$ & $\begin{array}{c}766 \\
528 \%\end{array}$ & $\begin{array}{c}269 \\
185 \%\end{array}$ & $\begin{array}{c}1451 \\
100.0 \%\end{array}$ \\
\hline
\end{tabular}

In Table 10 the results adjusted for respondents who did not answer questions about the ability to retain important employees and employee relationships in general are shown. As a result, it is clear that the perception of the item relationships between employees in general are correlated with the variable perceived ability to retain important employees. To test the hypothesis, a Spearman's rho correlation test was proceeded, the result can be seen in Table 11. 
Table 11. Correlations: Spearman's rho for perceived relationships between employees and perceived ability to retain important employees (Source: own elaboration, 2019).

\begin{tabular}{ccc}
\hline \multicolumn{2}{c}{ Correlations-Spearman's rho } & $\begin{array}{c}\text { Perceived Relationships } \\
\text { between Employees }\end{array}$ \\
\hline Perceived ability to retain an & Correlation Coefficient & $0.355^{* *}$ \\
important employee & Sig. (2-tailed) & 0.000 \\
& $\mathrm{~N}$ & 1451 \\
\hline
\end{tabular}

** Correlation is significant at the 0.01 level (2-tailed).

As can be seen in Table 11, there is a moderate positive and statistically significant relationship between organizational performance variable perceived ability to retain important employees and organizational performance variable perceived relationships among employees (Spearman's rho = $0.355 ; p<0.001$ ). Based on the above, we do not reject the second research hypothesis, and we can conclude that good relationships at the workplace with other employees positively affect the ability to retain important employees in industrial enterprises.

\section{Discussion}

Many organizations have to deal with an increasingly diversified workforce. It is not only aging that has made labor management more difficult because it is more diversified [88], but also the fact that employees are highly qualified and aware of their rights to work in an organization [89]. Global demographers have long predicted a parallel demographic shift from a balanced workforce of older and younger workers to an unbalanced workforce dominated by older workers [90] and emphasize the importance of sustainable human resource management, as well as maintaining or improvement the sustainable employability of their workforce [28]. It can be assumed that developing programs to encourage older workers to actively contribute to results and create added value in their organizations is a challenge that organizations should consider as an investment [91].

Therefore, in our opinion, it is important to consider the age diversity of the workforce when managing human resources in an organization. This will make it possible to take account of differences in attitudes of values and preferences and to exploit the coexistence of employees of different generations to achieve synergy of joint results. For this reason, it is possible to use the findings of the carried-out research and implement them into business practice. Investigated research suggests that there are significant differences between similar generations [35,43,48,92]. These differences seem more to be highlighted in the business environment when a number of issues arise in collaborative workplaces - notably in the area of knowledge sharing and knowledge transfer regarding the characteristics of the generations being compared.

The need to explore the motivation and willingness to share knowledge is emphasized by several authors $[93,94]$. Although human resources practices do not have direct impact on knowledge sharing, they have a positive indirect effect when they mediate relationship between commitment to organization and knowledge sharing [95]. This means that human resource management practices contribute to knowledge creation and create the emotional commitment needed for willingness of employees to share their knowledge [96]. Knowledge transfer is especially important for overcoming difficulties and increasing cooperation between generations, especially when younger and older employees work together in an organization [92].

We focused on the perception of relationships among employees and on how the perception of these relationships varies with different generations of employees, in the presented paper. Research has confirmed that employee relationships are perceived differently by different generations of employees. Research has shown that the younger the employees, the more they tend to positively evaluate the relationships between employees with each other. The study of unethical workplace behavior and the age categories of employees at risk of chicane has also demonstrated that age diversity plays role in workplace behavior towards colleagues [97]. We assume that differences in behavior towards colleagues 
are influenced by the age and generational diversity of employees. The perception of relationships between colleagues is incurred by values and accessibility, or openness to building relationships and the degree of experience, which varies from generation to generation of employees. The need to investigate the issue of relations between employees in terms of age diversity is also confirmed by another research. Millennium Generation employees are not just part of another generation, because they also share some of the value aspects and orientations of the previous generation. As a practical consequence, the behavioral and organizational characteristics that combine $X$ and $Y$ generation preferences should be identified in order to improve relationships between employees. The social implications of studying generational characteristics and tendencies in the workplace are an important social area, as it brings a new perspective on workplace relationships and leadership [98].

Although some authors have not confirmed that the relationship with co-workers has a significant impact on job satisfaction, they confirm that an appropriate working environment enhances employee loyalty, commitment and hence productivity [89]. However, other studies have confirmed that relationships have a significant impact on employee job satisfaction $[99,100]$. The presented research also confirmed that relations in the workplace have a significant impact on the work behavior of employees and the willingness to remain at work with the current employer in the organizations operating in Slovakia. The relationship between perceived relationships and perception of organizational performance in issues connected with recruiting and retaining staff has been confirmed by the results of the presented research. Research results have shown that the perception of workplace relationships as positive and the ability to retain important employees are positively interrelated. This finding needs to be incorporated in the sustainable human resource management.

Several studies deal with workplace conflicts and their impact on workplace relationships, wellbeing and employee performance [101-103]. The authors attribute an important role to managers' approach to conflicts in workplace [104,105]. The conflicts are seen as a symptom of management failure that should be avoided because it distracts attention from the primary goal of creating high-performance organizations [106]. The direct effects of culture on the direction and supportive leadership and team cohesion as well as on the mitigating impact of social culture on the relationship between leadership and working group cohesion are not negligible [107]. The organization's commitment to corporate social responsibility, especially in the social area and the approach of managers, play an important role in the perceived burden on performance and affect how employees feel safe at work $[3,108]$.

We have also assumed that the ability of an organization to retain important employees will be differently perceived by employees at different working positions. The managers perceived more positively the ability to retain important employees as production and administrative employees as confirmed results of presented research. An interesting area for exploring would be the perception of difference $s$ between managers and other employees and the ability to retain important employees in terms of gender diversity. Some research on the assumptions for managerial work declares differences in the approach to managerial work between men and women [109], but also in the conditions created for their work [110]. The presented results of carried out research and previous meta-analysis have shown that the proposed functional model together with the research results after their application can have a positive impact on sustainable human resource management and afterward on organizational performance of the enterprises.

\section{Conclusions}

The presented study also has several limitations and future proposals. The authors aimed on sustainable human resource management with focus on the potential of employees. The relationship between the development (education) of employees, motivation and performance related to each other has been described. However, in order to benefit from mutual influence of these areas of employees' behavior and acting, it is needed for organizations to dispose with employees who have the necessary potential, which can be partially identified by their observable working behavior. This observable behavior is a manifestation of the achieved competences, which can be e further developed, but only to 
the extent that the employee's potential allows. The research focused on important areas of human resource management, recruiting, and retaining employees, which form the basis for ensuring the employees with the needed potential and competencies.

The methods used in the research have enabled to compare the collected data in terms of the perception of organizational performance issues by different generations and employees at different job positions. The results of the research showed the importance of mutual communication and knowledge about opinions and preferences of different generational groups of employees but also the importance of the interest of management in understanding the perception of organizational performance by employees at other, maybe lower positions. The analysis of the research results based on the research question 1 revealed important information that employees at lower positions perceive worse the organizational ability to recruit and retain the necessary employees than do employees at managerial positions. In doing so, production employees have a worse perception of the organization's ability to recruit and to retain employees, closely followed by administrative employees.

Limitations of the research were that only perceived organizational performance and only selected issues of perceived organizational performance were analyzed. This allowed only limited analysis and testing. The limitation of research can be also that statistical processing and evaluation of the collected data has a descriptive character, which is caused by the formulation of research questions and research hypotheses. The limitation of the research may be also its geographical limitation, since it was carried out only in the Slovak Republic.

The research presented in this paper was mainly focused on the analysis of perceived organizational performance issues with regard on various generational groups of employees in industrial enterprises. Based on the evaluation of research questions it has been shown that different generations of employees have different perceptions within selected issues of organizational performance of the enterprises. It is the ability to attract important new employees and retain important employees within demonstration the organizational performance of an enterprise that is crucial in ensuring the competitive advantage of an organization through competitive human potential. If employees feel that an enterprise is unable to attract and retain important employees, it may negatively affect its perception and commitment to the organization and their performance provided.

From the overall evaluation of the data for the analyzed issues, it can be argued that most employees stated that the ability to attract important employees is perceived worse and much worse (50.99\% - 750 respondents) compared to the sum of options much better and better $(48.2 \%-709$ respondents). Therefore, encouraging management of industrial enterprises to focus on social activities and activities at local communities, with an emphasis on attracting important employees who are key to the organization's prosperity, as part of sustainable human resource management. One way is to develop sustainable, functional business strategies that focus on succession and use of the internal labor market in human resource management. One possibility is to develop sustainable, functional business strategies that focus on succession and use of the internal labor market within human resource management. Another option for declaring an organization's commitment in the social area is to introduce outplacement programs into business practice.

The analysis of the research results based on research question 2, revealed differences in perception of workplace relationships. A significant finding of presented research is that the variable relationship between managers and other employees was perceived positively throughout the research group. Employees perceived worse and much worse the relationships which was declared by 577 (39.23\%) of respondents on the other side 880 of respondents which makes a total of $59.82 \%$ that perceive relations between managers and other employees better and much better. Improving the perception of this organizational performance item can be enhanced by maintaining effective communication between employees and management. This highlights the importance of the manager in influencing the employee satisfaction. Relationships between supervisors and employees are influenced to a large extent by the management methods and also the managerial skills of the supervisor. Therefore, it is important to develop and consolidate them through building a suitable organizational culture. 
Generally, within the whole group of respondents it is possible to consider relations among employees in general as better and much better where $10.40 \%$ respondents indicated the mentioned possibilities, which makes a $70.70 \%$ share of all respondents. On the other hand, 420 respondents think that relations between employees are worse and much worse, which makes $28.55 \%$ of all answers. Testing the research hypotheses identified a significant difference in the perception of the issue of organizational performance relationships between employees in general, where it was confirmed that members of different generations perceived relationships differently.

We recommend considering the aspect of generational diversity in the management of industrial enterprises, which is often neglected at present because management in industrial enterprises does not address human resource management conceptually, but only on the level of the application of management methods and practices. Testing the second research hypothesis revealed a significant relationship between the organizational performance variable the relationship between employees in general and the ability to retain important employees. Based on the above, we recommend that the management of industrial enterprises focuses their sustainable human resource management strategy on retaining important employees with an emphasis on improving workplace relationships that are demonstrably linked to job satisfaction, motivation and performance achievement. Based on the above, the authors of the paper intend to extend the research in the future to the field of exploring the interrelationship of generational diversity, sharing knowledge and performance management. The authors of the paper plan to test their functional model in the context of various aspects of generational diversity, but also of intergenerational cooperation. Finally, there is a plan to implement the obtained results in industrial enterprises of various sizes in order to prove the applicability of the model for all types of industrial enterprises and its importance for individual fields of sustainable human resource management.

Author Contributions: Conceptualization, resources and looking for the link with sustainability, writing-original draft preparation Z.G.B.; investigation and data curation Z.G.B. and A.S.; methodology A.S., K.K. and Z.G.B., visualization A.S. and Z.G.B.; software A.S. and Z.G.B., validation and formal analysis Z.G.B. and A.S.; writing-review and editing and supervision Z.G.B. and D.C. All authors have read and agreed to the published version of the manuscript.

Funding: This research was funded by the Ministry of Education, Science, Research and Sport of the Slovak Republic; the paper is a part of VEGA project No. 1/0348/17 "The impact of the coexistence of different generations of employees on the sustainable performance of organisations".

Conflicts of Interest: The authors declare no conflict of interest.

\section{References}

1. Leber, M.; Bastič, M.; Moody, L.; Schmidt Krajnc, M. A study of the impact of ergonomically designed workplaces on employee productivity. Adv. Prod. Eng. Manag. 2018, 13, 107-117. [CrossRef]

2. McKenna, S.; Richardson, J.; Manroop, L. Alternative paradigms and the study and practice of performance management and evaluation. Hum. Resour. Manag. Rev. 2011, 21, 148-157. [CrossRef]

3. Heffernan, M.; Dundon, T. Cross-level effects of High-Performance Work Systems (HPWS) on employee well-being: The mediating role of organisational justice. Hum. Resour. Manag. J. 2016, 26, 211-231. [CrossRef]

4. Anvari, A.F.; Soltani, I.; Rafiee, M. Providing the Applicable Model of Performance Management with Competencies Oriented. Procedia Soc. Behav. Sci. 2016, 230, 190-197. [CrossRef]

5. Čambál, M.; Chlpeková, A.; Gyurák Babel'ová, Z.; Lenhardtová, Z. Manažment Podniku: Kl'účové Manažérske Kompetencie (Business Management: Key Management Competencies), 1st ed.; Nakladatel'stvo STU: Bratislava, Slovakia, 2013; p. 354.

6. Barnes, J.; Liao, Y. The effect of individual, network, and collaborative competencies on the supply chain management system. Int. J. Prod. Econ. 2012, 140, 888-899. [CrossRef]

7. Feißel, A.; Peter, R.; Swart, E.; March, S. Developing an Extended Model of the Relation between Work Motivation and Health as Affected by the Work Ability as Part of a Corporate Age Management Approach. Int. J. Environ. Res. Public Health 2018, 15, 779. [CrossRef] 
8. Szabó, P.; Míkva, M.; Vaňová, J.; Marková, P. Employee performance in the context of the problems of measurement and evaluation in practice. Res. Pap. 2017, 25, 63-70. [CrossRef]

9. Gruman, J.A.; Saks, A.M. Performance management and employee engagement. Hum. Resour. Manag. Rev. 2011, 21, 123-136. [CrossRef]

10. Betinová, Z.; Gyurák Babel'ová, Z.; Chlpeková, A. Talent management as precondition for sustainable performance of industrial companies. In Proceedings of the Recenzovaný Sborník Příspěvků Vědecké Interdisciplinární Mezinárodní Vědecké Konference Doktorandů a Odborných Asistentů (QUAERE), Hradec Králové, Czech Republic, 25-29 May 2015; pp. 274-283.

11. Simanová, L.; Gejdoš, P. Application of selected methods and approaches for improvement of processes and their use in practice in companies of wood processing industry in Slovakia. Manag. Syst. Prod. Eng. 2019, 27, 162-165. [CrossRef]

12. Sujová, A.; Marcineková, K. Improvement of Business Processes-A Research Study in Wood-processing Companies of Slovakia. Procedia Econ. Financ. 2015, 34, 296-302. [CrossRef]

13. Papulová, Z.; Papula, J.; Oborilová, A. Process Management: A Comprehensive View of the Process Management Concept, 1st ed.; Kartprint: Bratislava, Slovakia, 2014.

14. Paulova, I.; Kucerova, M.; Mlkva, M. The application of process approach in quality management in terms of Slovak republic. In Proceedings of the 20th International Danube-Adria-Association-forAutomation-and-Manufacturing Symposium, Vienna, Austria, 25-28 November 2009; pp. 893-894.

15. Klementová, J.; Sedliačiková, M.; Gurová, H.D.; Malá, D. Performance of Processes in Quality Management of Companies Providing Services. Glob. J. Bus. Econ. Manag. Curr. Issues 2018, 8, 138-144. [CrossRef]

16. Zavadsky, J.; Korenkova, V.; Zavadska, Z.; Kadarova, J.; Tucek, D. Competences in the Quality Management System Evaluation Based on the Most Worldwide Used Key Performance Indicators. Qual. Access Success 2019, 20,29-41. Available online: https://www.srac.ro/calitatea/en/arhiva/2019/QAS_Vol.20_No.169_Apr.2019.pdf (accessed on 17 September 2019).

17. Delaney, T.J.; Huselid, M.A. The Impact of Human Resource Practices on Perceptions Organizational Performance. Acad. Manag. J. 1996, 39, 949-969. [CrossRef]

18. Harel, G.H.; Tzafrir, S.S. The Effect of Human Resource Management Practices on the Perceptions of Organizational and Market Performance of the Firm. Hum. Resour. Manag. 1999, 38, 185-199. [CrossRef]

19. Brewster, C.H.; Gooderham, P.N.; Mayrhofer, W. Human resource management: The promise, the performance, the consequences. J. Organ. Eff. People Perform. 2016, 3, 181-190. [CrossRef]

20. Bailey, T.R. Discretionary Effort and the Organization of Work: Employee Participation and Work Reform Since Hawthorne; Teachers College and Conservation of Human Resources: Manhattan, NY, USA, 1993.

21. Delery, J.; Gupta, N. Human resource management practices and organizational effectiveness: Internal fit matters. J. Organ. Eff. People Perform. 2016, 3, 139-163. [CrossRef]

22. Chang, W.J.A.; Huang, T.C. The impact of human resource capabilities on internal customer satisfaction and organisational effectiveness. Total Qual. Manag. 2010, 21, 633-648. [CrossRef]

23. Stankevičiūtè, Ž.; Savanevičienè, A. Raising the Curtain in People Management by Exploring How Sustainable HRM Translates to Practice: The Case of Lithuanian Organizations. Sustainability 2018, 10, 4356. [CrossRef]

24. Ozolina-Ozola, I. The Impact of Human Resource Management Practices on Employee Turnover. Procedia Soc. Behav. Sci. 2014, 156, 223-226. [CrossRef]

25. Chams, N.; García-Blandón, J. On the importance of sustainable human resource management for the adoption of sustainable development goals. Resour. Conserv. Recycl. 2019, 141, 109-122. [CrossRef]

26. Mazur, B. Sustainable Human Resource Management in theory and practice. Econ. Manag. 2014, 1, 158-170. [CrossRef]

27. Vivares-Vergara, J.A.; Sarache-Castro, W.A.; Naranjo-Valencia, J.C. Impact of human resource management on performance in competitive priorities. Int. J. Oper. Prod. Manag. 2016, 36, 114-134. [CrossRef]

28. Ybema, F.J.; Tinka, V.; Karen, D. HR practices for enhancing sustainable employability: Implementation, use, and outcomes. Int. J. Hum. Resour. Manag. 2017, 1-22. [CrossRef]

29. Lepak, D.P.; Marrone, J.A.; Takeuchi, R. The relativity of HR systems: Conceptualising the impact of desire employee contributions and HR philosophy. Int. J. Technol. Manag. 2004, 27, 639-655. [CrossRef]

30. Mlkva, M.; Vanova, J.; Szabo, P. Evaluation of employees' performance-Identification of problems and proposals for their elimination. AD ALTA J. Interdiscip. Res. 2017, 7, 219-224. 
31. Moore, D.; Cheng, M.; Dainty, A. Competence, competency and competencies: Performance assessment in organisations. Work Study 2002, 51, 314-319. [CrossRef]

32. Jurík, L.; Sakál, P. Building sustainable development in industrial enterprises through competency models of managers. Výkonnost Podn. 2016, 6, 61-68. Available online: http://www.vusem.sk/public/userfiles/files/ VP2_2016.pdf (accessed on 7 January 2019).

33. Banerjee, P.; Gupta, R.; Bates, R. Influence of Organizational Learning Culture on Knowledge Worker's Motivation to Transfer Training: Testing Moderating Effects of Learning Transfer Climate. Curr. Psychol. 2017, 36, 606-617. [CrossRef]

34. Ehnert, I.; Harry, W.; Zink, K.J. Sustainability and Human Resource Management. Developing Sustainable Business Organizations; Springer: Berlin, Germany, 2014. [CrossRef]

35. McCrindle, M.; Wolfinger, E. The ABC of XYZ: Understanding the Global Generation, 1st ed.; University of New South Wales: Sydney, Australia, 2010.

36. Spišáková, A.; Vraňaková, N.; Koltnerová, K.; Chlpeková, A. Design of the implementation of concept of age management in industrial companies. Fórum Manažéra 2016, 12, 52-56. Available online: https: //www.forummanazera.sk/archiv/2016_Forum\%20Manazera\%202_online.pdf (accessed on 22 August 2019).

37. Starecek, A.; Vranakova, N.; Koltnerova, K.; Chlpekova, A.; Caganova, D. Factors affecting the motivation of students and their impact on academic performance. In Proceedings of the 14th International Conference on Efficiency and Responsibility in Education (ERIE), Prague, Czech Republic, 8-9 June 2017; pp. 396-407.

38. Caganova, D.; Starecek, A.; Bednarikova, M.; Hornakova, N. Analysis of factors influencing the motivation of generations $\mathrm{Y}$ and $\mathrm{Z}$ to perform in the educational process. In Proceedings of the 15th IEEE International Conference on Emerging eLearning Technologies and Applications (ICETA), Stary Smokovec, Slovakia, 26-27 October 2017; pp. 69-74. [CrossRef]

39. Kupperschmidt, B. Multigenerational employees: Strategies for effective management. Health Care Manag. 2000, 19, 65-76. [CrossRef]

40. Berkup, S.B. Working with Generations X and $Y$ in Generation Z Period: Management of Different Generations In Business Life. Mediterr. J. Soc. Sci. 2014, 5, 218-229. [CrossRef]

41. Gyurák Babel'ová, Z.; Stareček, A.; Cagáňová, D.; Fero, M.; Čambál, M. Perceived Serviceability of Outplacement Programs as a Part of Sustainable Human Resource Management. Sustainability 2019, 11, 4748. [CrossRef]

42. Feeney, P. The Baby Boomer Generation: A Lifetime of Memoriesm; The History Press: Stroud, Gloucestershire, UK, 2015.

43. Gravett, L.; Throckmorton, R. Bridging the Generation Gap. How to Get Radio Babies, Boomers, Gen Xers, and Gen Yers to Work Together and Achieve More; Career Press: Franklin Lakes, NJ, USA, 2007.

44. Bristow, J. Baby Boomers and Generational Conflict, 1st ed.; Palgrave Macmillan: Hampshire, UK, 2015. [CrossRef]

45. Rood, A.S. Understanding Generational Diversity in the Workplace: What Resorts Can and are Doing. J. Tour. Insights 2010, 1. [CrossRef]

46. Tay, A. Managing generational diversity at the workplace: Expectations and perceptions of different generations of employees. Afr. J. Bus. Manag. 2011, 5, 249-255. [CrossRef]

47. Martin, N.M.; Fulton, D. Factoring for X: An Empirical Study of Generation X's Materialistic Attributes. J. Manag. Mark. Res. 2008, 1, 65. Available online: https://www.researchgate.net/publication/228488948_ Factoring_for_X_An_Empirical_Study_of_Generation_X\T1\textquoterights_Materialistic_Attributes (accessed on 11 July 2019).

48. Tolbize, A. Generational differences in the workplace. In Research and Training Center on Community Living; Univeristy of Minnesota: Minneapolis, MN, USA, 2008. Available online: https://rtc.umn.edu/docs/2_18_ Gen_diff_workplace.pdf (accessed on 10 January 2019).

49. Mulvanity, E.W. Generation X in the Workplace: Age Diversity Issues in Project Teams; Project Management Institute Annual Seminars \& Symposium: Nashville, TN, USA, 2001. Available online: https://www.pmi.org/ learning/library/generation-x-workplace-age-diversity-style-7904 (accessed on 28 August 2018).

50. Coupland, D. Generation X, 1st ed.; St. Martin's Press: New York, NY, USA, 1991.

51. Saridakis, G.; Cooper, C.L. Research Handbook on Employee Turnover. New Horizons in Management Series, 1st ed.; Edward Elgar Publishing Limited: Cheltenham, UK, 2016. [CrossRef] 
52. Benson, J.; Brown, M. Generations at work: Are there differences and do they matter? Int. J. Hum. Resour. Manag. 2011, 22, 1843-1865. [CrossRef]

53. Dziewanowska, K.; Pearce, A.; Zupan, N. Generation Y's expectations regarding their future employment relationships poses a challenge for their employers. J. Hum. Resour. Manag. 2016, 19, 1-12. Available online: https://www.jhrm.eu/wp-content/uploads/2016/04/GENERATION-Ys-EXPECTATIONS-OF-THEIRFUTURE-EMPLOYMENT-RELATIONSHIOS-POSE-A-CHALLENGE-FOR-THERI-EMPLOYERS.pdf (accessed on 14 September 2019).

54. Sheahan, P. Generation Y: Thriving and Surviving with Generation Y at Work, 1st ed.; Hardie Grant Books: South Yarra, Australia, 2005.

55. Su, C.H.J.; Tsai, C.H.K.; Chen, M.H.; Lv, W.Q. U.S. Sustainable Food Market Generation Z Consumer Segments. Sustainability 2019, 11, 3607. [CrossRef]

56. Kamenidou, I.C.; Mamalis, S.A.; Pavlidis, S.; Bara, E.Z.G. Segmenting the Generation Z Cohort University Students Based on Sustainable Food Consumption Behavior: A Preliminary Study. Sustainability 2019, 11, 837. [CrossRef]

57. Cho, M.; Bonn, M.A.; Han, S.J. Generation Z's Sustainable Volunteering: Motivations, Attitudes and Job Performance. Sustainability 2018, 10, 1400. [CrossRef]

58. Kucharcikova, A.; Miciak, M.; Malichova, E.; Durisova, M.; Tokarcikova, E. The Motivation of Students at Universities as a Prerequisite of the Education's Sustainability within the Business Value Generation Context. Sustainability 2019, 11, 5577. [CrossRef]

59. Zupan, N.; Mihelic, K.K.; Aleksić, D. Knowing me is the Key: Implications of Anticipatory Psychological Contract for Millennials' Retention. In Psychology of Retention: Theory, Research and Practice; Coetzee, M., Ferreira, N., Potgieter, I.L., Eds.; Springer Nature: Cham, Switzerland, 2018. [CrossRef]

60. Grenčíková, A.; Španková, J. Labour Migration Trends in the Slovak Republic. J. Sci. Pap. Econ. Sociol. 2016, 9, 158-167. [CrossRef] [PubMed]

61. Rodriguez, M.; Boyer, S.; Fleming, D.; Cohen, S. Managing the Next Generation of Sales, Gen Z/Millennial Cusp: An Exploration of Grit, Entrepreneurship, and Loyalty. J. Bus. Bus. Mark. 2019, 26, 43-55. [CrossRef]

62. Mohr, K.A.J.; Mohr, E.S. Understanding Generation Z Students to Promote a Contemporary Learning Environment. J. Empower. Teach. Excell. 2017, 1. [CrossRef]

63. Weeks, K.P.; Schaffert, C. Generational Differences in Definitions of Meaningful Work: A Mixed Methods Study. J. Bus. Ethics 2017, 156, 1045-1061. [CrossRef]

64. O'Reilly, C.A.; Caldwell, D.F. The impact of normative social influence and cohesiveness on task perceptions and attitudes: A social information processing approach. J. Occup. Psychol. 1985, 58, 193-206. [CrossRef]

65. Manning, F.J.; Fullerton, T.D. Health and Well-Being in Highly Cohesive Units of the U.S. Army. J. Appl. Soc. Psychol. 1988, 18, 503-519. [CrossRef]

66. O'Reilly, C.A.; Caldwell, D.F.; Barnett, W.P. Work Group Demography, Social Integration, and Turnover. Adm. Sci. Q. 1989, 34, 21-37. [CrossRef]

67. Jiang, K.; Liu, D.; McKay, P.F.; Lee, T.W.; Mitchell, T.R. When and how is job embeddedness predictive of turnover? A meta-analytic investigation. J. Appl. Psychol. 2012, 97, 1077-1096. [CrossRef]

68. Hiltrop, J.M. The impact of human resource management on organisational performance: Theory and research. Eur. Manag. J. 1996, 14, 628-637. [CrossRef]

69. Wright, P.; McMahan, G.; McWilliams, A. Human Resources as a Source of Sustained Competitive Advantage. Int. J. Hum. Resour. Manag. 1994, 5, 301-326. Available online: https://www.researchgate.net/ publication/234075755_Human_Resources_as_a_Source_of_Sustained_Competitive_Advantage (accessed on 10 September 2019). [CrossRef]

70. Chang, A.; Bordia, P. A multidimensional approach to the group cohesion-group performance relationship. Small Group Res. 2001, 32, 379-405. [CrossRef]

71. Birknerová, Z. Organizačné Správanie: Od Teórie k Aplikácii v Praxis (Organizational Behaviour: From Theory to Application); Via Bibliotheca: Pezinok, Slovakia, 2011.

72. Nibler, R.; Harris, K.L. The Effects of Culture and Cohesiveness on Intragroup Conflict and Effectiveness. J. Soc. Psychol. 2003, 143, 613-631. [CrossRef] [PubMed]

73. Man, D.C.; Lam, S.S. The effects of job complexity and autonomy on cohesiveness in collectivistic and individualistic work groups: A cross-cultural analysis. J. Organ. Behav. 2003, 24, 979-1001. [CrossRef] 
74. Tsaur, S.H.; Yen, C.H. Work-leisure conflict and its consequences: Do generational differences matter? Tour. Manag. 2018, 69, 121-131. [CrossRef]

75. Zhou, Z.E.; Meier, L.L.; Spector, P.E. The spillover effects of coworker, supervisor, and outsider workplace incivility on work-to-family conflict: A weekly diary design. J. Organ. Behav. 2019. [CrossRef]

76. Foy, T.; Dwyer, R.J.; Nafarrete, R.; Hammoud, M.S.S.; Rockett, P. Managing job performance, social support and work-life conflict to reduce workplace stress. Int. J. Product. Perform. Manag. 2019, 68, 1018-1041. [CrossRef]

77. Allen, D.G. Do organizational socialization tactics influence newcomer embeddedness and turnover? J. Manag. 2006, 32, 237-256. [CrossRef]

78. Ehnert, I. Sustainable Human Resource Management. A Conceptual and Exploratory Analysis from a Paradox Perspective, 1st ed.; Physica-Verlag Heidelberg: Berlin, Germany, 2009. [CrossRef]

79. Barrick, M.R.; Zimmerman, R.D. Hiring for retention and performance. Hum. Resour. Manag. 2009, 48, 183-206. [CrossRef]

80. Bacong, C.I.M.; Encio, H.A. Effect of Employee Relation to Job Performance in Engineering, Construction and Manufacturing Company. Asia Pac. J. Educ. Arts Sci. 2017, 4, 103-111. Available online: https: //pdfs.semanticscholar.org/22a2/342530262a4ad76e28f775a91ed9a51e3362.pdf (accessed on 15 June 2019).

81. Min, L.; Yong, S. Coworker's relation influence on individual job performance: A contextuanzing research. J. Chem. Pharm. Res. 2014, 6, 1986-1993. Available online: http://www.jocpr.com/articles/coworkers-relationinfluence-on-individual-job-performance-a-contextuanzing-research.pdf (accessed on 15 June 2019).

82. Ariani, D.W. Relationship with Supervisor and Co-Workers, Psychological Condition and Employee Engagement in the Workplace. J. Bus. Manag. 2015, 4, 34-47. [CrossRef]

83. Huang, C.C.; You, C.S.; Tsai, M.T. A multi-dimensional analysis of ethical climate, job satisfaction, organizational commitment, and organizational citizen-ship behaviors. Nurs. Ethics 2012, 19, 513-529. [CrossRef] [PubMed]

84. Gerlach, G.I. Linking justice perceptions, workplace relationship quality and job performance: The differential roles of vertical and horizontal workplace relationships. Ger. J. Hum. Resour. Manag. Z. Pers. 2019, 33, 337-362. [CrossRef]

85. Fu, K.J.; Hsieh, J.Y.; Wang, T.K. Fostering Employee Cooperation Behavior in the Federal Workplace: Exploring the Effects of Performance Management Strategies. Public Pers. Manag. 2019, 48, 147-178. [CrossRef]

86. Cooke, F.L.; Wang, J.; Bartram, T. Can a Supportive Workplace Impact Employee Resilience in a High-Pressure Performance Environment? An Investigation of the Chinese Banking Industry. Appl. Psychol. 2019, 68, 695-718. [CrossRef]

87. Cortina, J.M. What is coefficient alpha? An examination of theory and applications. J. Appl. Psychol. 1993, 78, 98-104. [CrossRef]

88. Burke, R.J.; $\mathrm{Ng}$, E. The changing nature of work and organizations: Implications for human resource management. Hum. Resour. Manag. Rev. 2006, 16, 86-94. [CrossRef]

89. Raziqa, A.; Maulabakhsh, R. Impact of Working Environment on Job Satisfaction. Procedia Econ. Financ. 2015, 23, 717-725. [CrossRef]

90. Mooseley, J.L.; Dessinger, J.C. Training Older Workers and Learners: Maximizing the Workplace Performance of an Aging Workforce; John Wiley \& Sons: Hoboken, NJ, USA, 2007.

91. Stroh, L.K.; Northcraft, G.B.; Neale, M.A. Organizational Behavior: A Management Challenge, 3rd ed.; Lawrence Erlbaum Associates: Mahwah, NJ, USA, 2002.

92. Bencsik, A.; Juhasz, T.; Machova, R. The Problems Created by the Arrival of Generations Z and $\mathrm{Y}$ in the Workplace. In Proceedings of the 5th International Conference on Management, Leadership and Governance (ICMLG), Johannesburg, South Africa, 16-17 March 2017; pp. 46-53.

93. Gagné, M.; Tian, A.W.; Soo, C.; Zhang, B.; Ho, K.S.B.; Hosszu, K. Different motivations for knowledge sharing and hiding: The role of motivating work design. J. Organ. Behav. 2019, 40, 783-799. [CrossRef]

94. Wang, W.T.; Hou, Y.P. Motivations of employees' knowledge sharing behaviors: A self-determination perspective. Inf. Organ. 2015, 25, 1-26. [CrossRef]

95. Jia, X.; Liao, S.; Van der Heijden, B.; Guo, Z. The effect of socially responsible human resource management (SRHRM) on frontline employees' knowledge sharing. Int. J. Contemp. Hosp. Manag. 2019, 31, 3646-3663. [CrossRef] 
96. Camelo-Ordaz, C.; García-Cruz, J.; Sousa-Ginel, E.; Valle-Cabrera, R. The influence of human resource management on knowledge sharing and innovation in Spain: The mediating role of affective commitment. Int. J. Hum. Resour. Manag. 2011, 22, 1442-1463. [CrossRef]

97. López-Cabarcos, M.Á.; Vázquez-Rodríguez, P.; Gieure, C. Gender and age differences in the psychosocial risk factors of workplace bullying. Psychol. Mark. 2017, 34, 1023-1030. [CrossRef]

98. Torsello, D. Generation Y workers an empirical framework for cultural and organizational aspects. Empl. Relat. Int. J. 2019, 41, 1330-1347. [CrossRef]

99. Castillo, J.X.; Cano, J. Factors Explaining Job Satisfaction among Faculty. J. Agric. Educ. 2004, 45, 65-74. Available online: http://www.jae-online.org/attachments/article/298/45-03-065.pdf (accessed on 4 April 2019). [CrossRef]

100. Chandrasekar, K. Workplace Environment and Its Impact Organizational Performance in Public Sector organizations. Int. J. Enterp. Comput. Bus. Syst. 2011, 1, 1-19. Available online: http://www.ijecbs.com/ January2011/N4Jan2011.pdf (accessed on 10 February 2019).

101. Kuriakose, V.; Sreejesh, S.; Wilson, P.R.; MR, A. The differential association of workplace conflicts on employee well-being the moderating role of perceived social support at work. Int. J. Confl. Manag. 2019, 30, 680-705. [CrossRef]

102. Tafvelin, S.; Keisu, B.I.; Kvist, E. The Prevalence and Consequences of Intragroup Conflicts for Employee Well-Being in Women-Dominated Work. Hum. Serv. Organ. Manag. Leadersh. Gov. 2019, 1-16. [CrossRef]

103. Ongori, H. Organisational Conflict and its Effects on Organisational Performance. Res. J. Bus. Manag. 2009, 3, 16-24. [CrossRef]

104. Massey, G.R.; Dawes, P.L. Functional and Dysfunctional Conflict in the Context of Marketing and Sales; University of Wolverhampton: Telford, UK, 2004. Available online: https://pdfs.semanticscholar.org/ 2185/2558e6b11284a87d75685a52a5b495dace57.pdf (accessed on 10 February 2019).

105. Amason, A.C. Distinguishing the Effects of Functional and Dysfunctional Conflict on Strategic Decision Making: Resolving a Paradox for Top Management Teams. Acad. Manag. J. 1996, 39, 123-148. [CrossRef]

106. Currie, D.; Gormley, T.; Roche, B.; Teague, P. The Management of Workplace Conflict: Contrasting Pathways in the HRM Literature. Int. J. Manag. Rev. 2017, 19, 492-509. [CrossRef]

107. Wendt, H.; Euwema, M.C.; van Emmerik, I.J.H. Leadership and team cohesiveness across cultures. Leadersh. Q. 2009, 20, 358-370. [CrossRef]

108. Dunbar, C.G.; Li, Z.F.; Shi, Y. Corporate Social Responsibility and CEO Risk-Taking Incentives. SSRN 2017, 1-40. [CrossRef]

109. Birknerová, Z. Professional Preconditions for Successful Managerial Work. Adv. Asian Soc. Sci. 2012, 1, 67-71. Available online: https://www.researchgate.net/publication/277853933_Professional_Preconditions_ for_Successful_Managerial_Work (accessed on 20 March 2019).

110. Björk, L.; Härenstam, A. Differences in organizational preconditions for managers in genderized municipal services. Scand. J. Manag. 2016, 32, 209-219. [CrossRef]

(C) 2020 by the authors. Licensee MDPI, Basel, Switzerland. This article is an open access article distributed under the terms and conditions of the Creative Commons Attribution (CC BY) license (http://creativecommons.org/licenses/by/4.0/). 